\title{
norden
}

Nordsyn - ecodesign and energy labelling requirements for hot water storage tanks

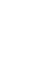


Nordsyn - ecodesign and energy labelling requirements for hot water storage tanks

ISBN 978-92-893-4374-9 (PRINT)

ISBN 978-92-893-4375-6 (PDF)

http://dx.doi.org/10.6027/ANP2015-785

ANP 2015:785

C Nordic Council of Ministers 2015

Layout: Erling Lynder

Cover photo: Ragnar Th. Sigurdsson/ARCTIC IMAGES

Photos: Signelements

The quality of the tables in this publication is slightly distorted, but based on the best available materials.

This publication has been published with financial support by the Nordic Council of Ministers. However, the contents of this publication do not necessarily reflect the views, policies or recommendations of the Nordic Council of Ministers.

www.norden.org/nordpub
Nordic co-operation

Nordic co-operation is one of the world's most extensive forms of regional collaboration, involving Denmark, Finland, Iceland, Norway, Sweden, and the Faroe Islands, Greenland, and Åland.

Nordic co-operation has firm traditions in politics, the economy, and culture. It plays an important role in European and international collaboration, and aims at creating a strong Nordic community in a strong Europe.

Nordic co-operation seeks to safeguard Nordic and regional interests and principles in the global community. Common Nordic values help the region solidify its position as one of the world's most innovative and competitive.

Nordic Council of Ministers

Ved Stranden 18

DK-1061 Copenhagen $\mathrm{K}$

Phone (+45) 33960200

www.norden.org 


\section{Nordsyn - ecodesign and energy labelling requirements for hot water storage tanks}

Preface

Summary $\quad 6$

Which products must comply with the requirements? 8

What are the requirements for energy labelling? $\quad 10$

What are the requirements for ecodesign? 12

What are the requirements for information and documentation?

Where can I find information? 
The European Commission published four regulations concerning ecodesign and energy labelling requirements of appliances for space heating and water heating (Regulations: 811/2013, 812/2013, $813 / 2013$ and $814 / 2013$ ) in the Official Journal 6th of September 2013. The first requirements will apply from 26 September 2015.

In January 2015, the Commission published a guideline on these regulations that contains a section with frequently asked questions (FAQ). Only the regulations are legally binding - the guideline itself is not. However, it is helpful for better understanding the regulations. It is available here: https://ec.europa.eu/energy/ sites/ener/files/documents/ GuidelinesSpaceWaterHeaters_ FINAL.pdf

The Nordic market surveillance authorities have issued a series of fact sheets/guides to help manufacturers and importers of appliances prepare for the new requirements. Four of these fact sheets have been developed by Nordsyn, which is a Nordic cooperation aiming for more efficient market surveillance of ecodesign and energy labelling. Nordsyn's partners are the Swedish Energy Agency/Energimyndigheten, the Danish Energy Agency/ Energistyrelsen, the Finnish Safety and Chemicals Agency/Tukes, the Norwegian Water Resources and Energy Directorate/Norges vassdrags-og Energidirektorat, and the Iceland Construction Authority/ Mannvirkjastofnun.

\section{- "Fact sheet on ecodesign and} energy labelling requirements for electric heat pumps and electric boilers".

- "Fact sheet on ecodesign and energy labelling requirements for electric heat pump water heaters and electric conventional water heaters".

- "Fact sheet on ecodesign and energy labelling requirements for hot water storage tanks".

- "Fact sheet on energy labelling requirements for packages of water heaters and solar devices".
The Norwegian Water Resources and Energy Directorate (NVE) has also developed two additional fact sheets:

- "Fact sheet on ecodesign and energy labelling requirements for oil- and gas-fired boilers".

- "Fact sheet on energy labelling requirements for packages of space heaters/combination heaters, temperature controls and solar devices".

Together, these fact sheets cover the most common space and water heating appliances on the Nordic market. However, some appliances are not covered by these regulations, e.g. micro CHP appliances and gas-fired water heaters. The individual fact sheets refer to one another when relevant and it is therefore recommended to have them all in order to gain their full benefit.

The fact sheets summarise the contents of the Regulations and are addressed to manufacturers, importers and other interested 
parties. The fact sheets are not legally binding and they do not substitute the Regulations and, in the event of doubt, the Regulations are applicable (any binding interpretation can only be made by the EU court). The fact sheets have been developed by the Danish Technological Institute and Viegand
Maagøe A/S, Denmark, as part of Nordsyn and of the Nordic Prime Ministers' overall green growth initiative: The Nordic Region leading in green growth under the Nordic Council of Ministers - read more at www.nordicway.org or at www.norden.org/greengrowth

October 2015

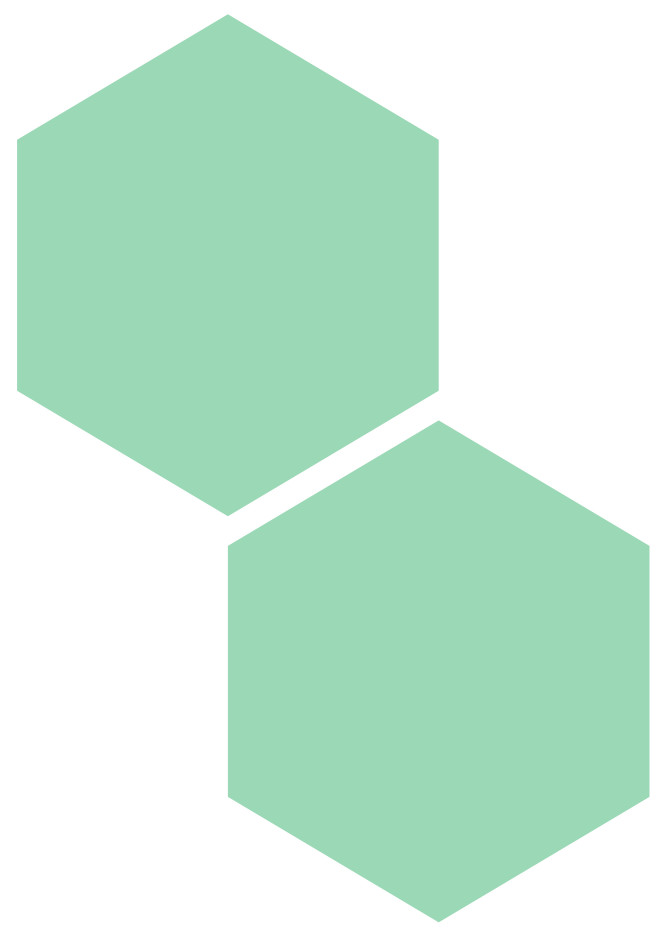




\section{Summary}

\author{
Are you a manufacturer or \\ importer of hot water storage \\ tanks? \\ Please be aware that hot water \\ storage tanks must meet the \\ ecodesign requirements. This \\ means that the product is \\ designed not to exceed maximum \\ allowed standing energy loss.
}

Hot water storage tanks must also be energy labelled.

\section{Which products?}

The Ecodesign Regulation applies to:

- Hot water storage tanks with a maximum storage volume of 2000 litres, including those tanks integrated in packages of water heaters and solar devices.

The Energy Labelling Regulation applies to:

- Hot water storage tanks with a maximum storage volume of 500 litres.

\section{When?}

The ecodesign regulations for hot water storage tanks applicable from 26 September 2017 introduce requirements for:

- The standing energy loss depending on storage volume.

- Information requirements (from 2015).

The energy labelling regulations for hot water storage tanks applicable from 26 September 2015 introduce requirements for:

- The provision of a printed EU energy label and a product fiche.

- Information on the energy class in advertisements and technical promotion material.

- The provision of electronic versions of the EU energy label and product fiche to dealers for products placed on the market with a new model identifier.

- The display of the energy label and product fiche when the products are offered for sale through the internet.

\section{Who?}

You are responsible for ensuring and documenting compliance with the requirements if you are:

- A manufacturer in the EEA producing hot water storage tanks to be placed on the market in the EEA.

- An importer of hot water storage tanks from a country outside the EEA to be placed on the market in the EEA.

- An authorised representative in the EEA for a manufacturer that is situated in a country outside the EEA.

The responsible parties mentioned above are hereinafter referred to as suppliers.

Dealers of water heaters and hot water storage tanks are responsible of ensuring that each product, at the point of sale, bears the energy label provided by the supplier, clearly visible. 
The EEA (European Economic Area) includes the EU member states and the EFTA countries.

\section{Why?}

Standing losses from hot water storage tanks account for a large share of energy loss in European households. Consequently, the EU has decided to reduce the energy loss from hot water storage tanks by introducing requirements for the maximum allowed standing energy loss and by introducing energy labelling.

\section{Where can I find more information?}

You can find the relevant regulations on the last page of this fact sheet, or read more about ecodesign and energy labelling on the webpage of your national market surveillance authority or the Commission (https://ec.europa.eu/energy/en/topics/energyefficient-products/heaters).

\section{Disclaimer}

This fact sheet presents the contents of the Regulations and is addressed to manufacturers, importers and other interested parties. This fact sheet is not legally binding and does not substitute the Regulations. In the event of doubt, the Regulations are applicable, and any binding interpretation can only be made by the EU court. 


\section{Which products must comply with the requirements?}

Ecodesign requirements for hot water storage tanks with a maximum storage capacity under 2000 litres will come into force on 26 September 2017.

A hot water storage tank is a vessel for storing hot water for direct use and/or space heating purposes, including any additives, and that is not equipped with any heat generator, except possibly one or more back-up immersion heaters. The back-up immersion heater is an electric resistance heater that is part of a hot water storage tank and generates heat only when the external heat source is disrupted (including during maintenance periods), or out of order, or that is part of a solar hot water storage tank and provides heat when the solar heat source is not sufficient to satisfy required comfort levels.

A distinction is made between water heaters, combination heaters and hot water storage tanks. The water heater generates and transfers heat to deliver drinking or sanitary hot water and includes a heat generator. Water heaters have separate requirements for ecodesign and energy labelling see "Fact sheet on ecodesign and energy labelling requirements for electric heat pump water heaters and electric conventional water heaters". In addition to providing space heating, combination boilers must also be designed to provide hot water and to connect to an external water supply. There are additional requirements for combination boilers' ecodesign and energy labelling. These requirements are described in "Fact sheet on ecodesign and energy labelling requirements for electric

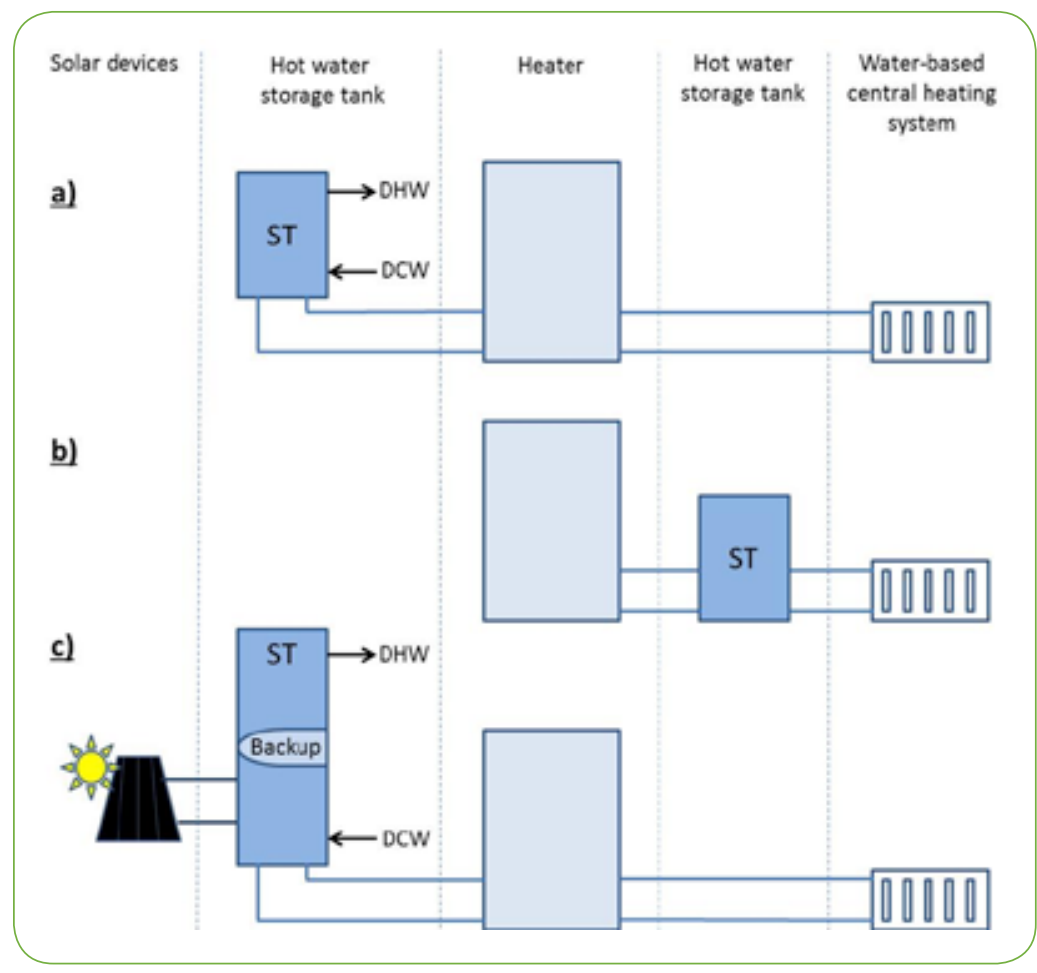

Figure 1: Different types of hot water storage tanks 
heat pumps and electric boilers" and "Fact sheet on ecodesign and energy labelling requirements for oil- and gas-fired boilers".

Figure 1 outlines three different types of hot water storage tanks: a) is a storage tank for domestic hot water supplied with heat from a space heater, e.g. a boiler, b) is a storage tank for space heating purposes, e.g. a buffer tank for a heat pump, c) is a solar hot water storage tank for domestic hot water with a back-up immersion heater. 


\section{What are the requirements for energy labelling?}

The requirements for energy labelling of hot water storage tanks only apply to hot water storage tanks with a maximum storage volume of 500 litres.

Hot water storage tanks must be labelled with the EU energy label. The label is identical in all the EU countries and includes pictograms instead of text, so that the label can be easily understood in all countries.

The label has the recognizable red and green arrows and the A-G scale is expanded with the energy class $\mathrm{A}^{+}$.

The supplier is responsible for providing a printed energy label together with each hot water storage tank.

\section{Energy efficiency classes on the label}

The label for hot water storage tanks includes a single scale and the energy classes will be introduced in two stages according to the schedule in Table 1. From 26 September 2015 an energy label with energy classes from $A$ to $G$ is required, and from 26 September 2017 a label with energy classes from $\mathrm{A}^{+}$to $\mathrm{F}$ is required.

\section{Determination of the energy classes}

The energy label for hot water tanks is based on the standing energy

Table 1: Plan for the introduction of energy classes

\begin{tabular}{ll}
\hline Energy classes & Energy label from \\
\hline$A-G$ & 26 September 2015 \\
$A^{+}-F$ & 26 September 2017 \\
\hline
\end{tabular}

\section{Be aware:}

The actual measurement results without addition of tolerances must be used for declaration of the energy efficiency class and other required declarable values. 


\section{Energy label for hot water}

storage tanks

The label to the left is required from stage one, i.e. 2015. The label to the right is required from stage two, i.e. 2017.

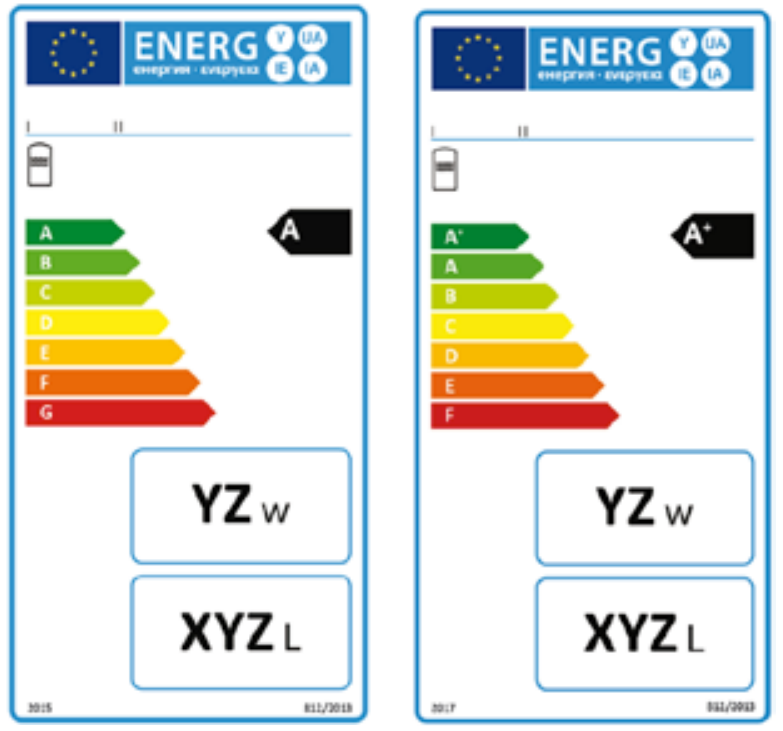

\section{Energy classes}

Table 2 describes the relationship between energy classes and seasonal space heating energy efficiency for hot water storage tanks.

\section{Table 2: Energy classes for hot water storage tanks}

\begin{tabular}{|c|c|}
\hline Energy efficiency class & Standing loss $S$ in Watts, with storage volume $V$ in litres \\
\hline$A^{+}$ & $S<5.5+3.16 \cdot v^{0.4}$ \\
\hline$A$ & $5.5+3.16 \cdot v^{0,4} \leq s<8.5+4.25 \cdot v^{0,4}$ \\
\hline B & $8,5+4,25 \cdot v^{0,4} \leq s<12+5,93 \cdot v^{0,4}$ \\
\hline C & $12+5.93 \cdot v^{0.4} \leq S<16.66+8.33 \cdot v^{0.4}$ \\
\hline D & $16,66+8,33 \cdot v^{0,4} \leq S<21+10,33 \cdot v^{0.4}$ \\
\hline E & $21+10,33 \cdot v^{0,4} \leq S<26+13,66 \cdot v^{0,4}$ \\
\hline $\mathrm{F}$ & $26+13.66 \cdot v^{0.4} \leq S<31+16.66 \cdot V^{0.4}$ \\
\hline G & $S>31+16,66 \cdot v^{0.4}$ \\
\hline
\end{tabular}




\section{What are the requirements for ecodesign?}

From 26 September 2017 the standing energy loss from hot water storage tanks must not

$$
16.66+8.33 * V^{0.4} \text { Watt }
$$
exceed the following level: 


\section{What are the requirements for information and documentation?}

\section{Energy labelling}

\section{Energy label and product fiche}

All hot water storage tanks placed on the market from 26 September 2015 must be provided with a printed energy label and a product fiche. A product fiche may include several models of hot water storage tanks from the same supplier. See the guidelines for product fiches in the Regulation on Energy Labelling, Annex IV.

Furthermore, electronic versions of the energy label and the product fiche must be made available to dealers for products placed on the market with a new model identifier. The layout of the electronic energy label must be identical with the printed label and the electronic versions of the label and the fiche must include the same information as the printed versions

\section{Information in technical promotion material and in advertisements}

Relevant technical promotion material and advertisements for hot storage tanks shall include information on the energy class of the units. Further information is available in Regulation 812/2013/ EU, Article 3 and 4.

\section{Labelling on the internet}

The electronic energy label and product fiche must be shown on the display in proximity to the price when hot water storage tanks are offered for sale or hire through the internet. The label and the product fiche may be shown using a "nested display".

\section{Ecodesign}

\section{CE marking and EC declaration of conformity}

Hot water storage tanks covered by the ecodesign requirements must be CE marked when they are placed on the market in the EEA countries.

Furthermore, an EC declaration of conformity must be available from which it must appear that the product complies with the requirements of the regulation. Consequently, the reference number of Regulation EU No 814/2013 must be mentioned in the declaration of conformity.
You can find the requirements for the contents of an EC declaration of conformity in the Ecodesign Directive 2009/125/EC Annex VI.

\section{Ecodesign and energy labelling \\ Technical documentation}

The supplier is responsible for making sure that there is technical documentation for the hot water storage tank when placing it on the EEA market. The technical documentation must show that the hot water storage tank is constructed in conformity with the ecodesign requirements and that the energy labelling of the hot water storage tanks is correct. The technical documentation must be compiled by the manufacturer.

For all hot water storage tanks, you can find the requirements for technical documentation and information to be made available on the manufacturer's website in Regulation 812/2013/EU Annex V and in Regulation 814/2013/EU Annex II. 
The market surveillance authorities of EEA countries may request the technical documentation, and you must provide it within a maximum of ten days after receiving the request.

The documentation relating to ecodesign requirements must be stored for a period of ten years after the last model of that product has been manufactured. In the case of energy labelling requirements, the documentation must be stored for five years.

\section{Measurement and calculation methods}

Reliable, accurate and reproducible measurement methods based on generally accepted measurement techniques must be used. A reproducible measurement method means that the measurements can be repeated with the same result.

Measurements must always be carried out in accordance with the Regulations. 


\section{Where can I find information?}

The webpages of the national market surveillance authorities and the Commission (https://ec.europa. eu/energy/en/topics/energy-

efficient-products/heaters) contain

more information about policies, new regulatory requirements, guidance, contact information, and links to relevant legislation.

\section{Legislation}

COMMISSION REGULATION

(EU) No 814/2013 of 2 August

2013 implementing Directive

2009/125/EC of the European

Parliament and of the Council

with regard to ecodesign

requirements for water heaters

and hot water storage tanks.

DIRECTIVE 2009/125/EC OF THE EUROPEAN PARLIAMENT AND

OF THE COUNCIL of 21 October

2009 establishing a framework for the setting of ecodesign requirements for energy-related products (recast).

\section{COMMISSION DELEGATED}

REGULATION (EU) No

$812 / 2013$ of 18 February

2013 supplementing Directive

2010/30/EU of the European

Parliament and of the Council with regard to the energy labelling of water heaters, hot water storage tanks and packages of water heater and solar device.

\section{DIRECTIVE 2010/30/EU OF THE} EUROPEAN PARLIAMENT AND OF THE COUNCIL of 19 May 2010 on the indication by labelling and standard product information of the consumption of energy and other resources by energy-related products (recast).

\section{COMMISSION DELEGATED}

REGULATION (EU) No518/2014 of 5 March 2014 amending Commission Delegated Regulations (EU) No 1059/2010, (EU) No 1060/2010, (EU) No 1061/2010, (EU) No 1062/2010, (EU) No 626/2011, (EU) No 392/2012, (EU) No 874/2012, (EU) No 665/2013, (EU) No $811 / 2013$ and (EU) No 812/2013 with regard to labelling of energy-related products on the internet.

These regulations cover hot water storage tanks as well as electric water heaters and heat pump water heaters, and oiland gas-fired water heaters.

\section{Where can I find help and guidance?}

You can get help to understand the requirements and answers to your questions by contacting your national market surveillance authority for ecodesign and energy labelling. 


\section{norden}

Nordic Council of Ministers

Ved Stranden 18

DK-1061 Copenhagen K

www.norden.org

ANP 2015:785

ISBN 978-92-893-4374-9 (PRINT)

ISBN 978-92-893-4375-6 (PDF) 